\title{
Review on Effects of Logistics Practices and Information Sharing on Supply Chain Performance
}

\author{
Diriba Ayele Gebisa \\ $\mathrm{PhD}$ Candidate \\ Guru Jambheshwar University of Science and Technology \\ Hariyana School of Business, India \\ Email: dirayele@gmail.com
}

\begin{abstract}
Today companies no longer compete merely as an independent business but rather as supply chains. Individual businesses no longer operate in isolation and neither should their strategic orientation be wholly individualistic. This attracted supply chain management concept to be used. Supply chain management primarily designed by firms to get competitive advantage over the rival firms and to overcome the intense global competition coming from globalization, innovation, free trade and economic cooperation formed in different region. The concept led to cooperation and integration among firms and with their suppliers, distributors, consumers, and transport agency. It is totally systematic coordination and management from upstream to downstream paths of an organization. The importance and research interest in supply chain management are growing from time to time; however, the number of professional materials and well-organized review literature is limited relative to the growing trend of the area. Therefore, this paper reviewed different supply chain management articles, reports, and books by concentrating on logistics practices and information sharing on supply chain performance to develop a well-organized research article that advances supply chain management understanding. Under the logistics practices, the major variables discussed were the effect of the road network, transportation cost, facility location, waiting time, inventory management and mode of transportation, whereas the effect information sharing discussed from the viewpoints of the level of information sharing and quality of information on supply chain performance.
\end{abstract}

\section{Keywords: Supply Chain Management, Logistics Practices and Information Sharing.}

\section{Introduction}

Companies today no longer compete simply as an independent business but rather as supply chains. Individual businesses no longer operate in isolation and neither should their strategic orientation be wholly individualistic. This has led to the development of the concepts of the supply chain. The origin of supply chain management goes back to the I940s and I950s when logistics was stressed on how to use mechanization to improve the very labor intensive processes, while the I980s marked the beginning of a change in logistics in the history of supply chain management and the term supply chain management was introduced first time by consultants in the early 1980s (Oliver and Webber, 1992). The logistics boomed in the I990s by the emergence of Enterprise Resource Planning (ERP) systems and the term supply chain management got widespread recognition as a result of the globalization of manufacturing since the midI990s (Council of Supply Chain Management Professionals, 2005).

As competition in the 1990s intensified and markets became global, organizations began to realize that it is not enough to improve efficiencies within an organization but their whole supply chain has to be made competitive through an integral collaboration of supply chain management (Gligor, Holcomb, Gligor, \& Holcomb, 2012) and that is why firms had integrated their physical distribution and logistics functions into the transportation and logistics perspective (Tan, 200I) (Tan, Kannan, Handeld, \& Ghosh, 1999; Childerhouse, Aitken, \& Towill, 2002). As (Fisher, 1997; Chen \& Paulraj, 2004) explained supply chain management is a composition of planning and control of materials, and information flows as well as the logistics activities not only internally but also externally between companies.

Supply chain management has no unique definitions; however the concepts of all the definitions go around the same concepts. Among the definitions given by scholars at the different time, the earliest definition of supply chain management is given as all functions within and outside a firm that support the value chain system to make and offer products to the customer (Cox, Blackstone, Spencer, I995). Lummus and Alber, (1997) also defined supply chain management as the network of entities (suppliers, carriers, manufacturing sites, distribution centers, retailers, and customers) through which material flows by adding certain value for each partner. Similar to the definition given by Cox et al. above, (Tan, 200I) linked supply chain management 
to two environments within an organization, and externally along the supply chain. Lastly, the Council of Supply Chain Management Professionals, (2015) defined supply chain management as management of all activities in sourcing and procurement, conversion, and all logistics activities.

Supply chain management is a key component of competitive advantage as striving to improve organizational productivity and profitability through internal and external integration (Gunasekaran et al., 2004). To be competitive and profitable supply chains should improve its supply chain performance from the angles of cost, activity time, customer responsiveness and flexibility (Beamon, 1998) and should deliver the best customer value at the lowest cost (Li, Ragu-nathan, Ragu-nathan, \& Rao, 2006). Similarly, for better performance of supply chain, a close integrated supply chain is compulsory (Huang \& Hsieh, 2015) and activities such as knowledge and information exchange, inventory and transport management should be made wisely (Kwak, 2016).

To overcome the pressure from globalization, industries have tried to upgrade their own operations using techniques of Total Quality Management, Enterprise Resource Planning, Business Process Reengineering, and Lean Technology. However, unable to totally overcome the pressure and this drives the adoptions of supply chain management, yet companies that have truly integrated their supply chains are still small (Georgise, Thoben, \& Seifert, 20I4).

Similarly, besides the pressure of globalization the report of ("United nations development programme ethiopia," n.d.; Debela, 2013) indicated the supply chain performances in Ethiopian influenced by logistics issues which resulted in delays, unreliability, and inefficiency of the logistics sector. The same report shows that Ethiopia incurs more than 2 percent production cost penalty and poor information to integrate supply chain management.

Generally, the purpose of this article was to increase supply chain management understanding and to enable the researcher to get an organized article reviewed on the effect of logistics practices and information sharing on supply chain performance. The paper specifically, focused on the effect of the road network, transportation cost, facility location, waiting time, inventory management and mode of transportation, level of information sharing and quality of information on supply chain performance.

\section{Definition of supply chain management}

There are no clear cut definitions of supply chain management, however, to make the study more manageable and meaningful this paper will discuss four more relevant definitions that encompass important activities of the supply chain. From this definition as Lee and Billington, (I995) defined supply chain is all facilities that connect together all supply chain partners. From this definition supply chain is a chain that connects the supply, process, and delivery of raw inputs and outputs throughout a system.

The second definition of supply chain management considers supply chain as a network work among supply chain partners; that is given in Investopedia (2016b), as a network between a company and its suppliers to produce and distribute a specific product, and the supply chain represents the steps it takes to get the product to the customer. Similarly, supply chain management is the network that links together partners over the entire value chain from the extraction of raw materials to its end of useful life by three important functions: (i) supply of materials to a manufacturer; (ii) the manufacturing process; and (iii) the distribution of finished goods through a network of distributors and retailers to a final customer (Aburadi, 2016).

The fourth definition of supply chain management is from the perspective of resource utilization to achieve competitive advantage and defined supply chain management as a system of effective utilization resource, technology, coordination of the manufacturing and logistics achievement of competitive advantage (Ferrell, Rogers, Ferrell, \& Sawayda, 2013). From all the definitions given, the summary of the important concept of supply chain management in all definitions are similar and revolve around the same circle. A key point in supply chain management is that the entire process must be viewed as one system. Therefore, the total success of the system is required within the supply chain rather than the sum of the merely individual parts.

\section{The objective of supply chain management}

The basic objective of supply chain management is to optimize the performance of the chain for the least cost possible. Supply chain management activities desired to: improve performance, retain competitive advantage, and meet long terms or short term needs of organizations (Krause, Ellram, Krause, \& Ellram, 1997). To achieve the objective supply chain needs to be efficient and to be efficient supply chain management is desired a higher level of quality information to lower total cost, the higher-order fulfillment rate and the shorter-order cycle time and this leads to high levels of customer satisfaction and quality (Li et al., 2006). Similarly, efficient supply chain is desired to make accessible and up-to-date marketing data and information (Li et al., 2006); delivering the best customer value at the lowest cost(Zeki \& Keskin, 20I I); to offer right quality at right cost (Busse, Schleper, Niu, Wagner, \& Busse, 2016), but now efficient supply chain management is beyond that to affect competitive advantage (such as price, cost, quality, customer satisfaction, and loyalty $\&$ delivery time) and performance such as (sales, market share, \& profitability). 
Generally, the objective of efficient supply chain management is to offer the best customer service and to reduce the cost of supply chain partners, but the two objectives seem two extreme ideas opposite to each other. However, since the game of supply chain management is a win-win game it benefits all parties rather than a win-loss game.

\section{Logistics Practices}

Logistics is one part of supply chain management practices that impact competitive advantage and overall organizational performance. Supply chain management practices are a set of activities undertaken in an organization to promote effective management of its supply chain. A well-managed logistics practices are expected to improve supply chain performance through cost, quality, delivery dependability, time to market, and product innovation ( Fernie, \& Mckinnon, 20I I). Logistic became a very important sector for the international sustainability of the companies. If a logistic company works with high performance, it will create a competitive advantage for both the company and country (Akdoğan \& Durak, 2016). The idea of logistics and supply chain management is an interaction of different processes and functions within a firm's network for the purpose of cost reduction and customer satisfaction (Bichou \& Gray, 2007).

Logistics is a multi-dimensional practice. It is a process of planning, implementing, and controlling the efficient and effective flow and storage of goods and related information. At the same time logistics deal with selection and arrangement of vehicles for transportation of materials and finished goods, and handling/holding of inventory in warehouse/storage until needed for production/consumption. An effective logistics practices shorten procurement time; minimize stock maintenance costs and shipment cost and time, offer secured and reliable services (Onay \& Kara, 2009; Aziz, Hillegersberg, \& Kumar, 20I0). The components of logistics are so broad but based on its relevance and research objective only six broad factors affecting logistics practices covered in this study including road network, inventory management, facility locations, transportation cost, mode of transportation, and waiting/lead time.

\section{I Road network}

For improved supply chain performance the need for availability of a road network is a key. Road network system is one of the most important infrastructures in any country as it provides the means to move people and goods. Road network design includes defining the routes and allocating the available resources and its performance evaluated by network reliability (Safeer, Anbuudayasankar, Balkumar, \& Ganesh, 2014). A road network system shows the standard of roads, connectivity, accessibility, linkages and movement; and poor road network connectivity will make supply chain management uncertain by disruption of transportation that create customer dissatisfaction, low customer responsiveness and low on time delivery (Parmar \& Shah, 2016).

\subsection{Transportation cost}

Minimization of transportation cost by the different model is an objective function of modern transport companies. Transportation models like North West Corner method, stepping stone method, least cost method, and others primary objective function is the minimization of transportation cost because it is a key area. Logistics companies can truly differentiate themselves and prove with cost reduction, and build high competitive advantage and supply chain performance (Neeraja, Mehta, \& Arti, 20I4). Sustained and effective freight transport is fundamental for economic development, where transport cost and supply chain performance is strongly correlated (Kuse, Endo, \& Iwao, 2010). Kotler \& Wong, ( n.d.) stated that improvements in physical distribution can yield tremendous improved supply chain performance for supply chain partners.

An empirical study on transportation cost show that the most important consideration in the selection of a particular mode of transport is its cost and nearly one-third of the total cost of logistics operations is transportation cost (Alan, Phil, \& Peter, 2006). A good transport system in logistics activities could provide better supply chain performance by reducing operation cost, and promoting service quality. An empirical finding of show a fall in transportation cost by one unit leads to inventory costs to be fall in triple and similarly, a one third to two third of the expenses of enterprises' logistics costs are spent on transportation and the cost of transportation on average account $6.5 \%$ of market revenue and $44 \%$ of logistics costs by (Wilson, 2004). However, transportation cost minimization constrained internally by quick-response pressures and externally by increasing traffic congestion on the road network (Fernie et al., 20II).

\subsection{Facility Location}

Facility location decisions also play a critical role in the efficiency of supply chain management. Location decisions may be the most critical and most difficult of the decisions needed to realize an efficient supply chain. Problems of facility location are of two types, selection of a facility from existing facilities and selecting the location for building the new facility. Location problems are highly uncertain in terms of travel time, cost and demand. For the location of a facility distance to the customer, time and costs have to be considered (Melo, Nickel, and Saldanha-da-Gama, 2009). Many models have been developed with an objective of cost minimization besides maximization the level of demand satisfaction that can be achieved by the effective utilization of available vehicles and resources (Boonmee, Arimura, \& Asada, 2017). 
Facility location has a long-term impact on the supply chain \& must be part of the firm's strategy. Facility location decisions play a crucial role in the supply chain management activities. As Krajewski, (2007) defined, facility location is the process of determining the geographic site for a firm's operations. Facility Location can be vital importance for the supply chain management from many reasons such as a limit of production capacity, expansion to a new market, and cost (Thanh, Bostel, and Péton, 2008).

Facility location decision influence the efficiency of supply chain management by influencing inventory and transportation decisions. Research show a strong relationship between location problem and inventory (Shen, Kremer, Ulieru, and Norrie, 2003) and the linear relationship between transportation cost and location decisions (Shen and Qi, 2007). Generally, locations decisions should consider the availability infrastructure, raw materials, nearness to the consumer, and availability of labor in order to make the right location decision to offer quick service delivery, to deliver at a minimum cost relative to competitors, and to offer quality service to improve supply chain performance.

\subsection{Average waiting time/Lead Time}

Waiting time is a time between placements of order to acceptance of product from the carrier at the destination point. Lead time is affected by the processing time of order and time to be taken by the carrier on delivery. Attention to lead time reduction originally aroused by JIT production, even though JIT literature stressed more on waste reduction than lead time reduction; and lead time reduction improves the speed of delivery (Treville, Shapiro, \& Hameri, 2004). Traffic congestion is a cost factor, comprised of time delay and rise operating expense. Traffic congestion has been defined as a condition of traffic delay (i.e., when traffic flow is slowed below reasonable speeds) because the number of vehicles trying to use a road exceeds the design capacity of the traffic network to handle it (Weisbrod, Donald, and George, 200I).

Congestion creates delay and uncertainty in logistics practices that increase inventory level, holding cost of inventory and make capital unproductive (Disney et al., 1997). Average waiting time also negatively affected by any additional time consumed within a distribution network due to uncertainty, unexpected delays at loading or unloading points, failures within the distribution network and unforeseen situations that totally negatively affect the efficiency of supply chain management (Stajniak, Hajdul, Foltynski, \& Krupa, 2008). An increase in average waiting time or factors that increase average waiting time can increase the delivery time/ lead-time, decrease customers dependency and reliability that negatively affect the performance of supply chain performance.

\subsection{Inventory control}

Effective inventory management is very critical for the success of supply chain performance. Inventory management is part of supply chain management function in which create an issue for the imbalance of inventory (Biman \& Chaki, 2012). The vast majority of supply chain literature is concerned with minimizing operation cost or maximizing profit but research on effects of inventory management on the performance of supply chains has only recently received significant attention (Melo et al., 2009). There is a direct relationship between the performance of supply chain management and inventories handling system of an organization (Dong, Carter and Dresner, 200I). Supply chain management concerned to inventory to overcome the problem of excess or shortage of inventory and for customer's satisfaction levels and flexibility to meet unpredicted demand (Lieberman et al, 1999).

Generally, for a better supply chain performance, effective inventory management is essential since inventory account a large percentage of assets of an organization. Therefore, while designing warehouse attention should be given to warehouse design, size and location to reduce transportation cost, holding cost, spoilage cost, insurance cost and leading time. Similarly, during the warehouse design as James, Tompkins, Jerry \& Smith (1998) stated considerations should be made to effective utilization of the space, loading and unloading areas, and equipment required to perform certain processes, the flexibility of moving products within the warehouse facility and protection of the items from damaging.

3.6 Type of vehicles / Mode of transportation

A critical problem in the mode of transportation is to find out the shortest time path between origin and destination. Decisions of transportation model have a critical impact on supply chain performance because the employed modes of transportation affect reliability, quality of service, capacity, delivery time, cost of transportation, and dependability. The decisions of the selection of the right transportation carriers based on the objective functions of the firms and the objective functions are either minimization of travel cost and travel time. Minimization of travel time leads to improvement in overall response and is sought for identifying the right path with minimum risk for transportation (Safeer et al., 20I4); travel cost (Ben-Tal et al, 20II); travel time (Barbarosoğlu, Özdamar, \& Çevik, 2002; and Yuan and Wang, 2009); and loading and unloading time (Barbarosoglu et al., 2002).

Transportation medium such as road is compounded with uncertainties that seriously affect the performance of supply chain and to address and overcome these challenges tools like optimization, \& fuzzy logic (Sheu et al.,2005), queuing theory (Mendoncaand \& Morabito, 200I), decision theory, and reference point method are used to overcome problems of logistics. 
Transport highly affected by inefficient loading and unloading, drop queuing, capacity loss, infrastructure loss, congestion loss and poor quality ( Mason, \& Lalwani, 2007).

The mode of transportation is an important consideration when desiring target level of supply chain performance. Besides the costs, the urgency of the shipment, the value of the goods being shipped as well as the size and weight of the goods to be moved need to be considered when determining the mode of transportation.

\section{Information sharing}

The emergence of new thinking in the managing of supply chain practices has been largely facilitated by developments information technology and it results in new opportunities for more effective collaborative transport management (Mason et al., 2007). Information sharing leads to high levels of supply chain integration, where supply chain integration is the amount of relationship between a supply chain partners (Lotfi, Sahran, Mukhtar, \& Zadeh, 20I3) and supply chain integration enables organizations to make dependable delivery, quick delivery of product to the market quickly. Information sharing and information quality contribute positively to customer satisfaction (Li et al., 2006).

As (Moberg, Cutler, Gross, \& Speh; 2002) revealed information sharing has two aspects: quantity and quality. Both aspects are important for the efficiency of supply chain management and have been treated as independent constructs in the supply chain management studies.

\section{I Level of information sharing}

Level (quantity aspect) of information sharing refers to the extent to which critical and proprietary information is communicated to one's supply chain partner (Monczka, Petersen, Handfield, \&, Ragatz; I998). Shared information can vary from strategic to tactical in nature or from information about logistics activities to general market and customer information (Monczka, et.al; 1998).

According to (Stein and Sweat, Sweat \& Killer; 1998), supply chain partners who exchange information regularly are able to work as a single entity, and information sharing is the important determinant of supply chain performance (Sukati, Bakar, Baharun, \& Yusoff, 2012). Supply chain partners together understand the needs of the end customer better and respond to market change quicker and information flow is the key to the performance of the supply chain (Childhouse and Towil, 2003).

\subsection{Quality of information sharing}

Quality of information sharing includes such aspects as the accuracy, timeliness, adequacy, and credibility of information exchanged (Monczka R. et.al; 1998). While information sharing is important, the significance of its impact on the efficiency of supply chain depends on what information is shared, when and how it is shared, and with whom (Chizzo; 1998).

Divergent interests and opportunistic behavior of supply chain partners, and informational asymmetries across supply chain affect the quality of information. It has been suggested that organizations will deliberately distort information that can potentially reach not only their competitors but also their own suppliers and customers (Mason-Jones, Towill; 1997) since information disclosure is perceived as a loss of power. Given these predispositions, ensuring the quality of the shared information becomes a critical aspect of the effective supply chain (Feldmann, Müller; 2003). Organizations need to view their information as a strategic asset and ensure that it flows with minimum delay and distortion.

\section{Supply chain performance and its measurement}

Performance measures and metrics are essential for effectively managing supply chain management practices. Performance measurement is the systematic way of quantifying the productivity of all efforts that lead to performance. Performance measures and metrics is a core activity for evaluation or comparison. Supply chain performance measurement offer sufficient information concerning finance, innovation, and improvement of a system for internal and external parties (Fawcett \& Magnan, I996).

The idea of measuring the supply chain performance emerged a long time ago and only a few supply chains are often overlooking performance measurement in critical supply chain contexts (Gunasekaran \& Kobu, 2007). As (Tetik, 2003) indicated performance is a degree of achievement attained by an enterprise within a specific period, whether expressed in a quantitative or qualitative way. Performance measurement is always a challenging issue due to lack of consensus on measurement dimensions due to the complex nature of supply chains (Kwak, 2016). Therefore setting a well-defined supply chain goal and performance indicators enhance the complexity of supply chain performance measurement (Panayides and Lun, 2009).

Traditionally supply chain performance is more relied if it measured and expressed by financial instruments but now multi-dimensional measurement is adopted to overcome the drawback of the traditional by incorporating non-financial indicators of performance (Başat, 2010). Different scholars tried to identify supply chain performance measurement as; cost, activity time, customer responsiveness and flexibility (Beamon, 1998); customer service and flexibility (Beamon, I999); delivery reliability, responsiveness, cost reduction, lead times, conformance to specifications and process improvements and time-tomarket (Panayides and Lun, 2009) and delivery time, quality consistency, productivity, sales costs, production time, delivery security, service quality, flexibility, market share, customer loyalty, activity, efficiency and conformance to standards are some of 
the performance measures (Morgan et al., 2009; \& Aziz et al., 2010). Lastly, quantitative and qualitative methods (Gunasekaran $\&$ Kobu, 2007) and delivery cycle, delivery speed, dependability on the supplier, manufacturing lead time, quick confirmation of orders, quick customer complaints handling, and frequency of new product development proposed as performance measurement instruments (Jayaram et al. I999).

The ability of the metrics to estimate the desired object of a system due to the variability of the nature of the performance is the greatest issues. As (Maskell, 1989) indicated whatever the proposed system of measurement, a system needs to follow seven basic principles of performance measurement, it should be (I) directly related to the firm's strategy; (2) nonfinancial measures; (3) vary between locations (departments or companies); (4) vary as situations do;(5) simple and easy; (6) provide fast feedback; and (7) inspire continuous development.

\section{Research Gaps}

We have no longer isolate and talk about suppliers, producers, distributors, and customers as they are managed and treated as an independent entity because of their interdependence in supply chain partners. Firms that efficiently use supply chain direct and utilize their effort towards customer service, profitability, and long-term superior performance. Based on the above literature review the following research gaps identified to be fulfilled by this research:

- More research has been carried out in a different dimension of supply chain management in case of a developed country but limited research in developing countries. However, still, there is a gap even in the developed country in case of supply chain management research because research remains hampered by missing information on effects of logistics and information sharing on supply chain performance as underlined by (De Langen, P., Nijdam, M., and Van Der Horst, M., 2007). Therefore, this research will fill the gap of literature on this issue.

- It is clear that there is a huge difference in technology and infrastructure facility, business environment, and industry development between a developed country and developing one. To be applicable in all environments it should cover heterogenic business environments and managers' attitudes that would increase the understanding of supply chain performance (Kwak, 2016). Therefore, the available literature and theoretical work are not totally fit with the context of a developing country. Therefore, this research will fill the gap of literature relevant to developing the country and different types of industries in general on the effects of logistics practices and information technology on supply chain performance.

- Lastly, prior research carried out on supply chain performance made in identical firms that limit the generalizability and applicability to another sector. Therefore, the finding is probably not applicable in all type of industries due to the difference in nature and size of firms. Therefore, to overcome this limitation, this research will cover different types of industries to improve the generalizations of its findings.

\section{References}

Aburadi, N. (2016). The Impact of Supply Chains on Productivity and Financial Performance of Power Producers in Australia

Akdoğan, M. Ş., \& Durak, A. (2016). Logistic and marketing performances of logistics companies : A comparison between Germany and Turkey. Procedia - Social and Behavioral Sciences, 235(October), 576-586. https://doi.org/I0.I0I6/j.sbspro.2016.II.084

Alan R., Phil C. \& Peter B., (2006). The Handbook of Logistics and Distribution Management 3rd Edition https://www.amazon.com/Handbook-Logistics-Distribution-Management/dp/0749446692

Aziz, R., Hillegersberg, J.V. and Kumar, K. (2010). Inter organizational relationships performance in third party logistics: conceptual framework and case study. In: Pioneering Solutions in Supply Chain Management, A Comprehensive Insight into Current Management Approaches, Erich Schmidt Verlag, pp.I05-I26.

Bayraktar, E., Gunasekaran, A., Koh, S. C. L., \& Tatoglu, E. (2010). An efficiency comparison of supply chain management and information systems practices: a study of Turkish and Bulgarian small- and medium-sized enterprises in food products and beverages, 7543. https://doi.org/I0.1080/00207540903174957

Barbarosoğlu, G., Özdamar, L. and A. Çevik,(2002). An interactive approach for hierarchical analysis of helicopter logistics in disaster relief operations, European Journal of Operational Research, vol. I40, pp. I I8-I33, 2002.

Beamon, B.M. (I998), "Supply chain design and analysis: models and methods", International Journal of Production Economics, Vol. 55, 28I-294.

Beamon, B.M. (I 999), "Measuring supply chain performance", International Journal of Operations \& Production Management, Vol. I9No. 3, pp. 275-292.

Bichou, K., \& Gray, R. (2007). A logistics and supply chain management approach to port performance measurement, 8839 https://doi.org/I0.I080/0308883032000I7 4454

Biman, B., \& Chaki, N. (2012). A Distributed Retail Beer Game for Decision Support System, 65(ICIBSoS), $278-284$. 
https://doi.org/I0.I0I6/j.sbspro.2012.II.I23

Boonmee, C., Arimura, M., \& Asada, T. (2017). International Journal of Disaster Risk Reduction Facility location optimization model for emergency humanitarian logistics. International Journal of Disaster Risk Reduction, 24(February), 485-498. https://doi.org/I0.10I6/j.ijdrr.2017.01.017

Busse, C., Schleper, M. C., Niu, M., Wagner, S. M., \& Busse, C. (2016). Supplier development for sustainability : contextual barriers in global supply chains. https://doi.org/IO.I I08/IJPDLM-I2-20I5-0300

Chen, I. J., \& Paulraj, A. (2004). Understanding supply chain management: Critical research and a theoretical framework. International Journal Production Research, 42(I), I3I-I63. https://doi.org/IO.I080/00207540310001602865

Childerhouse, P., Aitken, J., \& Towill, D. R. (2002). Analysis and design of focused demand chains, 20, 675-689.

Chizzo SA. 1998. Supplychain strategies: solutions for the customer-driven enterprise. Software magazine. Supplychain management directions supplement January4-9, 1998.

Corswant, Fredrik von, Anna Dubois, and Peter Fredriksson (2004), "Organizing activities in industrial networks: The case of Volvo S80," in 20th annual IMP conference. Copenhagen.

Council of Supply Chain Management Professionals. (20I5). CSCMP Supply Chain Management definitions. Retrieved from https://cscmp.org/imisO/CSCMP/Educate/SCM_Definitions_and_Glossary_of_Terms/CSCMP/Educate/SCM _Definitions_and_Glossary_of_Terms.aspx?hkey=60879588-f65f-4ab5-8c4b-68788I5ef92I

Council of Supply Chain Management( 2005). Supply Chain Operations Reference Model, SCOR version 7.0. Overview, 2005 , p. 7.

Cox, J.F., Blackstone, J.H., Spencer, M.S. (Eds), (I995). APICS Dictionary, American Production and Inventory Control Society, Falls Church, VA.

Debela, F. M. (2013). Logistics Practices in Ethiopia.

De Langen, P.W., Nijdam, M. and Van Der Horst, M. (2007). New indicators to measure port performance. Journal of Maritime Research,vol. 4, no. I, pp. 23-36.

Disney, S.M., Naim, M.M. and Towill, D.R. (1997) "Dynamic Simulation Modelling for Lean Logistics", International Journal of Physical Distribution and Logistics Management, Vol. 27, Issue 3, pp. I74-96.

Vendor-Managed Inventory and Bullwhip... (PDF Download Available). Available from: https://www.researchgate.net/publication/242344693_Vendor-

Managed_Inventory_and_Bullwhip_Reduction_in_a_Two-Level_Supply_Chain [accessed Apr 26 2018].

Dong, Y., C.R. Carter and M.E. Dresner. "JIT Purchasing and Performance: An Exploratory Analysis of Buyer and Supplier Perspectives," Journal of Operations Management, (I9:4), July 200I, pp. 47 I-483.

Fawcett, S. E., \& Magnan, G. M. (2008). Benefits , barriers , and bridges to effective supply chain management, I, $35-48$. https://doi.org/IO.I I08/I3598540810850300

Feldmann M, Müller S. (2003). An incentive scheme for true information providing in supplychains. OMEGA 2003;3I(2):63-73.

Fernie, J., \& Mckinnon, A. C. (20II). The grocery supply chain in the UK: improving efficiency in the logistics network The grocery supply chain in the UK: improving efficiency in the logistics network, 3969. https://doi.org/I0.I080/095939603200005I693

Ferrell, O. , Rogers, M., Ferrell L., \& Sawayda J. (2013.). A Framework for Understanding Ethical Supply Chain Decision Making A Framework for Understanding Ethical Supply Chain Decision Making, (September 20I3), $37-4$ I. https://doi.org/I0.1080/I046669X.2013.803428

Fisher, M.L., (1997). What is the right supply chain for your product? Harvard Business Review 75 (2), I05 \} II6.

Georgise, F. B., Thoben, K., \& Seifert, M. (2014). Supply Chain Integration in the Manufacturing Firms in Developing Country: An Ethiopian Case Study, 2014.

Gligor, D. M., Holcomb, M. C., Gligor, D. M., \& Holcomb, M. C. (20I2). review Understanding the role of logistics capabilities in achieving supply chain agility: a systematic literature review. https://doi.org/IO.I I08/I359854I2I I246594

Gunasekaran, A., \& Kobu, B. (2007). Performance measures and metrics in logistics and supply chain management : a review of recent literature ( $1995-2004)$ for research and applications, 7543(May). https://doi.org/I0.I080/00207540600806513

Gunasekaran, A., Patel, C. and Mcgaughey, R.E. (2004), "A framework for supply chain performance measurement”, International Journal of Production Economics, Vol. 87 No. 3, pp. 333-347

Ben-Tal, B., Chung, S. R. Mandala, and T. Yao( 20I I). Robust optimization for emergency logistics planning: Risk mitigation in humanitarian relief supply chains, Transportation research part B: methodological. vol. 45, pp. I I77-II89, 201 I.

Huang, Y., \& Hsieh, M. (2015). Exploring the most influenced financial determinants of supply chain management by cross- 
employing factor analysis approach and fuzzy set qualitative comparative analysis method, 7(5I), I-8. https://doi.org/I0.I I77/I6878I4015620329

Investopedia. (2016b). Supply Chain. Retrieved from: http://www.investopedia. com/terms/s/supplychain.asp

Jayaram, J., Droge, C. and Vickery, S.K. (I999), "The impact of human resource management practices on manufacturing performance”, Journal of Operations Management, Vol. I8 No. I, pp. I-20.

Kotler, P., \& Wong, V. (n.d.). Principles of Marketing.

Krajewski, L. J., 2007. Operations Management. 8th ed. New Jersey: Prentice Hall.

Krause, D. R., Ellram, L. M., Krause, D. R., \& Ellram, L. M. (1997). ; Success factors in supplier development.

Kuse, H., Endo, A., \& Iwao, E. (2010). Logistics facility, road network and district planning : Establishing comprehensive planning for city logistics, 2(3), 625I-6263. https://doi.org/I0.1016/j.sbspro.2010.04.035

Kwak, D. (2016). The impact of innovativeness on supply chain performance: is supply chain integration a missing link? https://doi.org/I0.I I08/SCM-02-2014-0058

Lee HL, Billington C (I995) The evolution of supply-chain-management models and practice at Hewlett-Packard. Interfaces 25(5):42-63

Lemma, H. R., Singh, R., \& Kaur, N. (2015). Determinants of supply chain coordination of milk and dairy industries in Ethiopia : a case of Addis Ababa and its surroundings. SpringerPlus. https://doi.org/I0.I 186/s40064-0I5-I287-x

Li, S., Ragu-nathan B., Ragu-nathan T. ., \& Rao S. (2006). The impact of supply chain management practices on competitive advantage and organizational performance, 34, I07-I24. https://doi.org/I0.1016/j.omega.2004.08.002

Lieberman, M.B., Helper, S., L. Demeester. 1999. The empirical determinants of inventory levels in high-volume manufacturing. Production and Operations Management, 8(I), 44-55.

Lotfi, Z., Sahran, S., Mukhtar, M., \& Zadeh, A. T. (2013). The Relationships between Supply Chain Integration and Product Quality. Procedia Technology, II(Iceei), 47I-478. https://doi.org/I0.1016/j.protcy.2013.I2.217

Lummus, R..; Albert, K.. (I997) Supply chain management: balancing the

supply chain with customer demand, Falls Church, VA Apics, I997.

Maskell, B. (1989), "Performance measurement for world class manufacturing”, Management Accounting, Vol. 67, No. 5, pp. 32-3. [Google Scholar] [Infotrieve]

Mason-Jones, R., \& Towill, D.(I997). Information enrichment: designing the supplychain for competitive advantage. Supply Chain Management 1997;2(4):I37-48.

Mason, R., Lalwani, C., Mason, R., \& Lalwani, C. (2007). Transport integration tools for supply chain management, 5567.

Mendonca and Morabito, (200I). Analysing emergency medical service ambulance deployment on a Brazilian highway using the hypercube model, Journal of the Operational Research Society (200I) vol. 52, pp. 26-270.

Melo, M.T., Nickel, S. and Saldanha-da-Gama, F. (2009), "Facility location and supply chain management - a review", European Journal of Operational Research, Vol. I96, pp. 40I-I2.

Ministry, F. (2015). FDRE Ministry of Industry E t h i o p i a n C e m e n t I n d u s t r y D e v e lo p m e n t S t r a t e g y.

Minten, B., Tamru, S., Kuma, T., \& Nyarko, Y. (2014). Structure and performance of Ethiopia's coffee export sector.

Moberg, C., Cutler, B., Gross, A, and Speh, T., (2002). Identifying antecedents of information exchange within supplychains. International Journal of Physical Distribution and Logistics Management 2002;32(9):755-70

Monczka, R.M., Petersen, K.J., Handfield, R.B. and Ragatz, G.L. (I998), "Success factors in strategic supplier alliances: the buying company perspective”, Decision Sciences, Vol. 29 No. 3, pp. 553-78

Morgan, N.A., Vorhies, D.W. and Mason, C.H. (2009), Market orientation, marketin capabilities, and firm performance, Strategic Management Journal, Vol. 30, No. 8, pp. 909-920.

Neeraja, B., Mehta, M., \& Arti, P. (2014). Supply Chain and Logistics For The Present Day Business. Procedia Economics and Finance, II(I4), 665-675. https://doi.org/I0.1016/S22I2-567I(I4)00232-9

Oliver, r. k. andWebber d., (I992). Supply chain management: logistics catches up with strategy. In christopher,M. G., (ed) Logistics, The Strategic Issue (London: Chapman \& Hall).

Onay, M. and Kara H.S. (2009), Lojistik dış kaynaklama uygulamalarının örgüt performansı üzerine etkileri, Ege Akademik Bakış, Vol. 9, No. 2, pp.593-622.

Panayides, P, \& Lun, Y. (2009). The impact of trust on innovativeness and supply chain performance. International Journal of Production Economics 2009; I22:35-46.

Parmar, V., \& Shah, H. G. (2016). A literature review on supply chain management barriers in manufacturing organization. International Journal of Engineering Development and Research, 4(I), 232I-9939.

Project, R. (2013). Incorporating Reliability Performance Measures into the Transportation Planning and Programming Processes.

Safeer, M., Anbuudayasankar, S. P., Balkumar, K., \& Ganesh, K. (20I4). Analyzing transportation and distribution in emergency humanitarian logistics. Procedia Engineering, 97, 2248-2258. 
https://doi.org/I0.I016/j.proeng.20I4.12.469

Shen, Z.M. and Qi, L., (2007). Incorporating inventory and routing costs in strategic

location models. European Journal of Operational Research I79, 372-389

Shen, W., Kremer, R., Ulieru, M. and Norrie, D. (2003). A collaborative agent-based infrastructure for internet- enabled collaborative enterprises", International Journal of Production Research, Vol. 4I No. 8, pp. 62I-I639.

Sheu J. (2007). An emergency logistics distribution approach for quick response to urgent relief demand in disasters, Transportation Research Part E: Logistics and Transportation Review, vol. 43, pp. 687-709, 2007.

Stajniak M., Hajdul M., Foltyński M., Krupa A., (2008), Transport i spedycja [Transport and spedition], Instytut Logistyki i Magazynowania, Poznań

Stein, T., \& Sweat, J. (1998). Killer supply chains. Informationweek, 708(9), 36-46.

Sukati, I., Bakar, A., Baharun, R., \& Yusoff, R. (2012). The Study of Supply Chain Management Strategy and Practices on Supply Chain Performance. Procedia - Social and Behavioral Sciences, 40, 225-233. https://doi.org/I0.I016/j.sbspro.2012.03.I85

Tan, K.C., Kannan, V.J., Hand"eld, R.B., Ghosh, S., (1999). Supply chain management: an empirical study of its impact on "rm performance. International Journal of Operations and Production Management I9 (10), I034\} 1052.

Tan, K. C. (200I). A framework of supply chain management literature. European Journal of Purchasing and Supply Management, 7(I), 39-48. https://doi.org/I0.I016/S0969-7012(00)00020-4

Tetik, S. (2003). İşletme performansını belirlemede veri zarflama analizi, Celal Bayar Üniversitesi Yönetim ve Ekonomi Dergisi, Vol. I0, No. 2, pp.22I-229

Thanh, P., Bostel, and Péton, (2008). A dynamic model for facility location in the design of complex supply chains. International Journal of Production Economics II3 (2):678-693.

Treville, S. De, Shapiro, R. D., \& Hameri, A. (2004). From supply chain to demand chain : the role of lead time reduction in improving demand chain performance, 21, 613-627. https://doi.org/I0.1016/j.jom.2003.I0.00I

Van Heck, E. \& Vervest, P. (2007). Smart business networks; how the networks win. Communications of the ACM, 50 (6), 28-37. Weisbrod G., Donald V., and George T. (200I). Economic Implications of Congestion, National Cooperative Highway Research Program Report 463,

Transportation Research Board, Washington, DC. http://onlinepubs.trb.org/ Onlinepubs/nchrp/nchrp_rpt_463-a.pdf

Wilson, R. (2004). I5th Annual State of Logistics Report. Council of Supply Chain Management Pro- fessionals. Available online: http:/ / www.cscmp.org/. Frank

Zeki, S., \& Keskin, H. (201I). The effect of supply chain integration on information sharing: Enhancing the supply chain performance, 24, I630-1649. https://doi.org/I0.1016/j.sbspro.201 1.09.016

\section{Copyrights}

Copyright for this article is retained by the author(s), with first publication rights granted to the journal. This is an open-access article distributed under the terms and conditions of the Creative Commons Attribution license (http://creativecommons.org/licenses/by/4.0/). 